\title{
Keep your head high: skulls on stakes and cranial trauma in Mesolithic Sweden
}

Sara Gummesson ${ }^{1}$, Fredrik Hallgren ${ }^{2} \&$ Anna Kjellström ${ }^{1, *}$

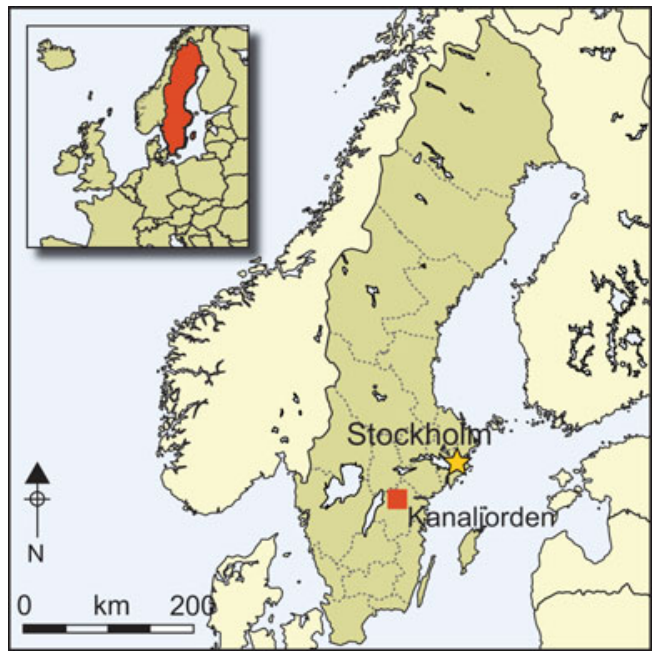

The socio-cultural behaviour of Scandinavian Mesolithic hunter-gatherers has been difficult to understand due to the dearth of sites thus far investigated. Recent excavations at Kanaljorden in Sweden, however, have revealed disarticulated human crania intentionally placed at the bottom of a former lake. The adult crania exhibited antemortem blunt force trauma patterns differentiated by sex that were probably the result of interpersonal violence; the remains of wooden stakes were recovered inside two crania, indicating that they had been mounted. Taphonomic factors suggest that the human bodies were manipulated prior to deposition. This unique site challenges our understanding of the handling of the dead during the European Mesolithic.

Keywords: Sweden, Mesolithic, burial practices, non-lethal violence, blunt force trauma

\section{Introduction}

Middle and Late Mesolithic Scandinavia (c. 9000-6000 cal BP) was populated by mobile or semi-sedentary groups subsisting by hunting, fishing and gathering. Only approximately 200 human burials dating to this 3000-year period have been investigated in Scandinavia, and knowledge of socio-cultural behaviours is limited. Mesolithic mortuary practices in the region are dominated by inhumation burials, often forming clusters, such as at Vedbæk, Denmark and Skateholm, southern Sweden (Larsson 1988, 2000; Brinch Petersen 2015; Sjögren \& Ahlström 2016). Of the approximately 250 known European burial sites (comprising around 2200 individuals), two-thirds have only one or two

1 Osteoarchaeological Research Laboratory, Department of Archaeology and Classical Studies, Stockholm University, Stockholm SE-106 91, Sweden

2 The Cultural Heritage Foundation, Stora Gatan 41, Västerås SE-722 12, Sweden

* Author for correspondence (Email: anna.kjellstrom@ofl.su.se) 


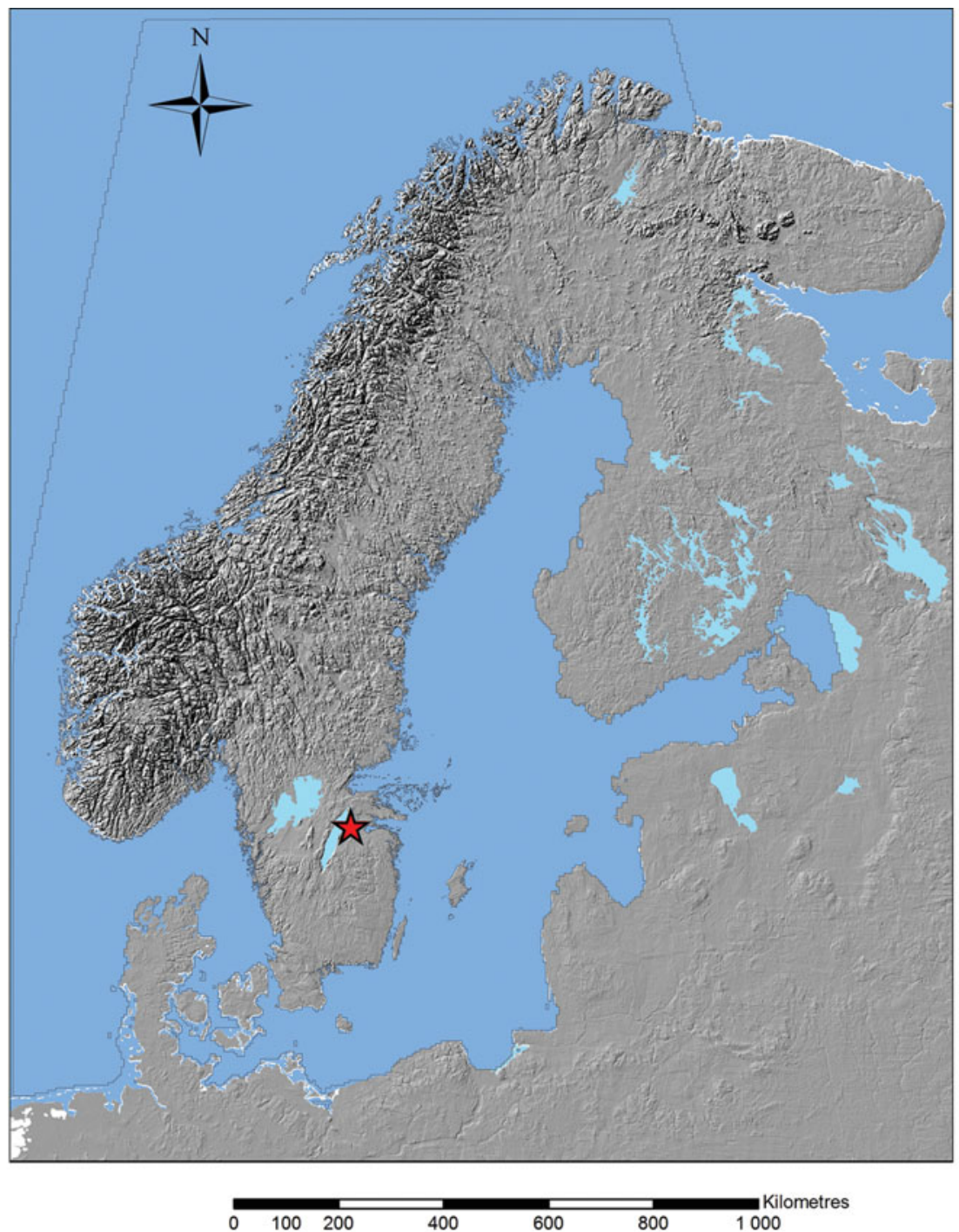

Figure 1. Map of Fennoscandia with a shoreline c. $7600 \mathrm{cal}$ BP. The location of Kanaljorden is marked by a star. Based on a shoreline map by Lars Andersson and Tore Paisse, SGU.

burials (Grünberg 2016: 13). Occurrences of disarticulated human remains are recorded at several sites (Larsson et al. 1981; Lindqvist \& Possnert 1999; Brinch Petersen 2016; Sørensen 2016). Here we discuss the site of Kanaljorden, Motala, in eastern-central Sweden, which contains unusual wetland depositions of disarticulated human and animal remains (Figure 1).

Kanaljorden is located on the margin of a small lake, close to the river Motala Ström (Figure 2). The eastern part of the site is a low hill that slopes towards a wetland, which extends to the west and north-west. Within the excavated area (black outline on Figure 2) were two small wetland basins. During $c$. 7700-7500 cal BP, the southern basin contained 


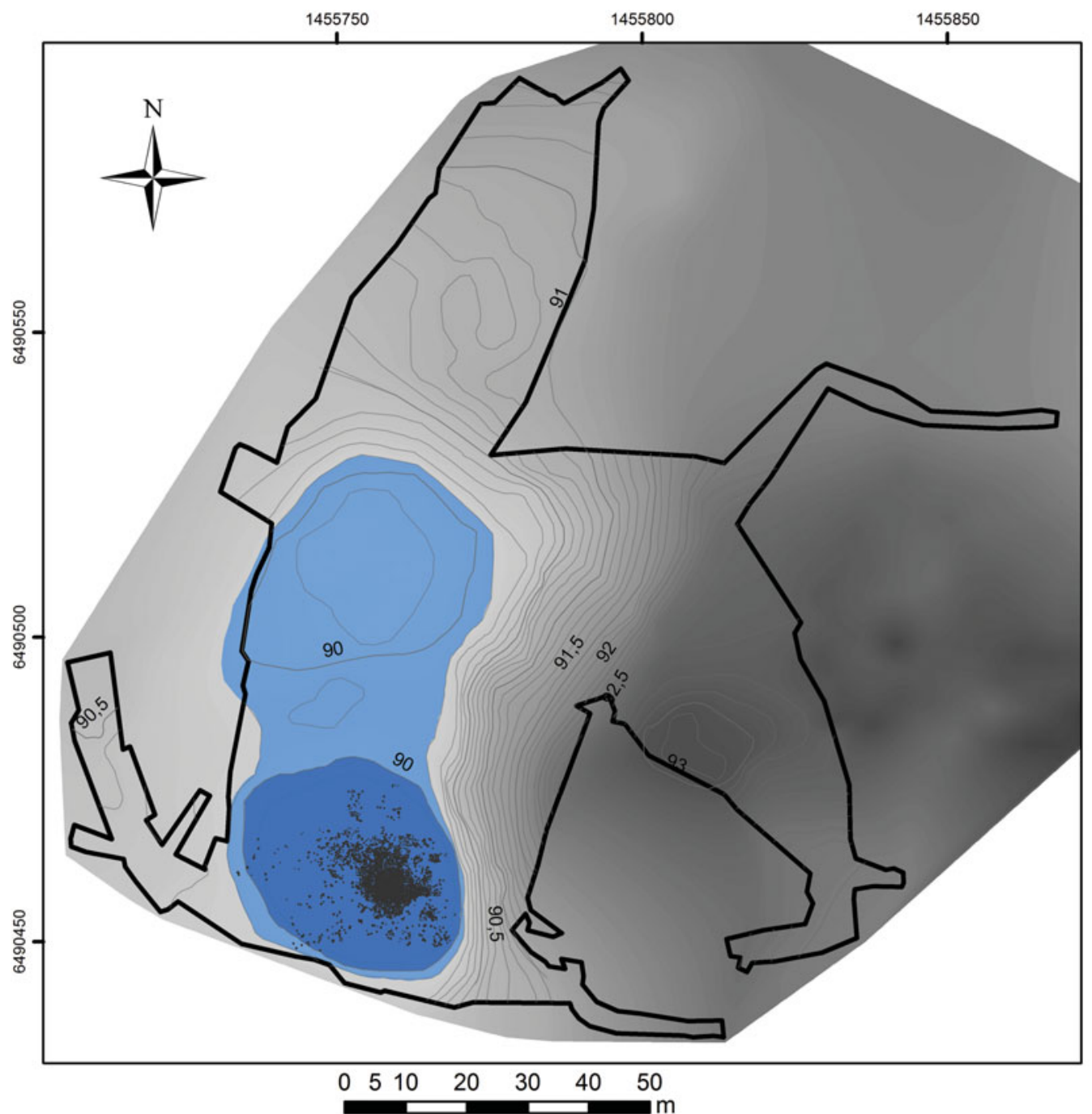

Figure 2. A model of the local topography at Kanaljorden. The black outline shows the excavated area. Map by Karin Berggren and Fredrik Hallgren.

open water of about $1 \mathrm{~m}$ in depth, while the northern basin consisted of a reed fen. The small lake in the southern basin was used for activities that included the construction of a $12 \times$ $14 \mathrm{~m}$ stone packing (a densely packed layer of large stones) on the bottom of the lake, and the subsequent deposition of human and animal remains in the water. Excavations in 20092013 uncovered this stone packing, which also included wooden stakes. On this structure, human and animal remains, as well as stone, bone and antler tools, had been deposited (Hallgren \& Fornander 2016). The context is dated to $c$. 8000-7500 cal BP. The shores of the small lake were settled in preceding periods of the Mesolithic, but there is no evidence of subsequent habitation. There are, however, two contemporaneous settlement sites on the banks of the nearby river (Figure 3). The site on the south bank (Strandvägen) also (C) Antiquity Publications Ltd, 2018 


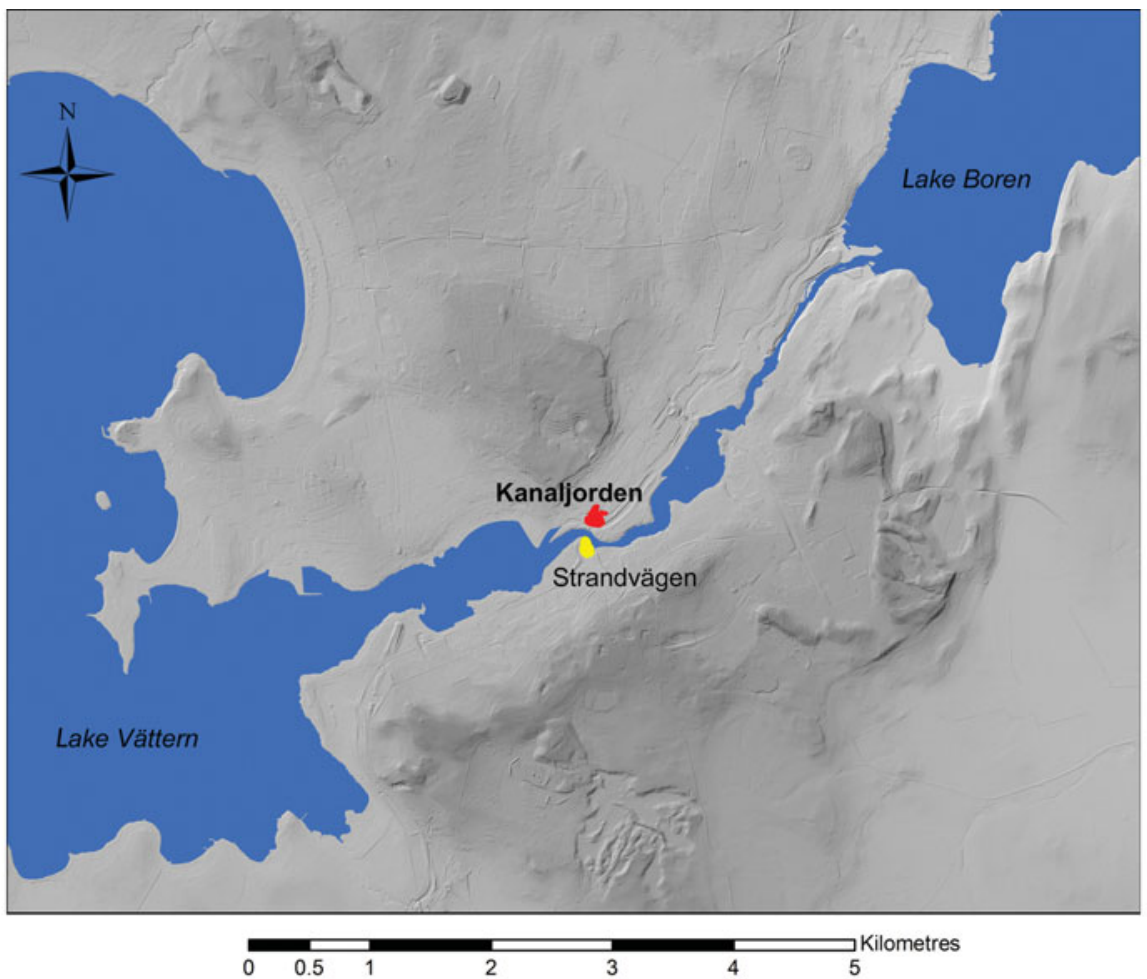

Figure 3. The topographic setting at Motala, with Kanaljorden (red) to the north of the river Motala Ström, and the site Strandvägen (yellow) to the south of the river. Map by Fredrik Hallgren, digital data from Lantmäteriet (licence no. MS2012/02954), (C) Lantmäteriet.

yielded inhumation burials, as well as wetland deposits of human remains in the adjacent river (Molin et al. 2014). The archaeological material from Motala reveals a society of hunter-gatherers with a broad subsistence economy that included fishing, the hunting of forest game and the gathering of wild plants, such as nuts and berries. Isotopic analyses of the human remains indicate a diet with varied protein sources, with a high proportion of aquatic resources (Eriksson et al. 2016). The results also indicate a degree of mobility, either logistical or residential (see Kelly 1983).

Preservation conditions at Motala were good and allowed detailed analyses of the osteological material. The osseous remains consist primarily of disarticulated, unburnt bones from both humans and animals. The osteological methods used follow standard protocols and are presented in Supplement 1 (S1) in the online supplementary material. Here we discuss the results of the analysis, the depositional history and possible interpretations of the human bone, which together provide new insights into the treatment of animal and human remains. Bioarchaeological perspectives of trauma patterns have previously been used to understand different life-ways in past populations (e.g. Walker 2001; Glencross 2011; Judd \& Redfern 2012; Knüsel \& Smith 2014), and are applied to this unique wetland deposition to highlight aspects of social organisation. 

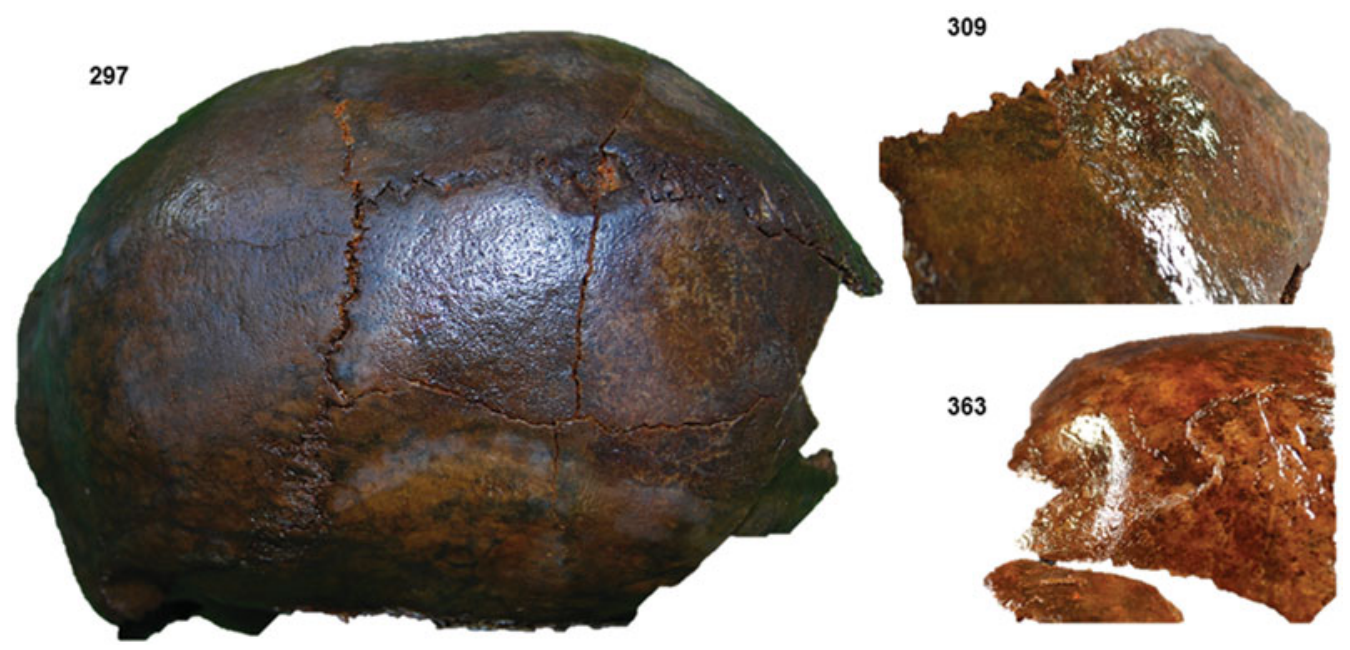

Figure 4. Examples of blunt force trauma from analysed individuals. Photograph: Sara Gummesson and Fredrik Hallgren.

\section{Results}

\section{The human remains: demography}

The assemblage includes 34 human elements; 19 cranial and 15 post-cranial elements (see S2). The remains of at least ten individuals_nine adults (based on the occurrence of occipital bones with a complete cruciform eminence) and one foetus/infant-were identified. The adults are primarily represented by relatively complete crania, and the infant by an almost complete skeleton. Two crania were identified as female and four as male (Table 1) (the sex assessments are in agreement with the genetic sex (S3)). As most of the crania were fragmented and incomplete, suture closure could be recorded in only two individuals. Both were male-one classified as an old adult $(50+$ years of age), and the other as a middle adult (35-50) (Table 1). In addition, two individuals were classified as at least of young adult age (20-35). Dental attrition could be assessed for eight elements, all indicating fully adult individuals. The length of the infant long bones suggest that they came from a foetus of approximately 36-40 weeks of age, indicating that the infant was stillborn or died soon after birth. Apart from the skeleton of the infant, all post-cranial human elements were disarticulated and came from fully developed individuals.

\section{The human remains: pathologies and trauma}

Minor pathological changes or anomalies were documented on five elements (S4). Seven individuals exhibited antemortem blunt force trauma to the head (see S4). In four of these individuals, nine round or elliptical depression fractures on the vault were documented (Figure 4). The injuries were shallow, affecting only the outer table and top section of the diploë. Additionally, healed blunt force injuries to the zygomatic process of a temporal bone, the zygomatic process of a frontal bone and a nasal bone were noted. (C) Antiquity Publications Ltd, 2018 
Table 1. Demographic data of the human bone finds from Kanaljorden. (X= presence of occipital bones and cruciform eminence.)

\begin{tabular}{|c|c|c|c|c|}
\hline Find no. & $\begin{array}{l}\text { Morphological sex } \\
\text { assessment }\end{array}$ & $\begin{array}{l}\text { Age } \\
\text { assessment }\end{array}$ & $\begin{array}{l}\text { Occipital bones and } \\
\text { cruciform eminence }\end{array}$ & Comments \\
\hline 295 (Ind 1) & female & young adult & $\mathrm{X}$ & fits with 363 \\
\hline 296 (Ind 2) & male & old adult & & \\
\hline 297 (Ind 3) & male & young adult & $\mathrm{X}$ & \\
\hline 298 (Ind 4) & & $\begin{array}{l}\text { young adult/ } \\
\text { middle adult }\end{array}$ & & \\
\hline 299 (Ind 5a) & & adult & & \\
\hline 299 (Ind 5b) & & adult & & \\
\hline 299 (Ind 5c) & & young adult & & \\
\hline 299 (Ind 5d) & & adult & & \\
\hline 300 (Ind 7) & & middle adult & $\mathrm{X}$ & \\
\hline 301 (Ind 8) & & adult & $\mathrm{X}$ & \\
\hline 302 (Ind 9) & male & young adult & & \\
\hline 303 (Ind 10) & & infant & & \\
\hline 306 (Ind 12) & male? & young adult & & \\
\hline 307 & & adult & & fits with 317 and 1913 \\
\hline 308 & & adult & & \\
\hline 309 & male & young adult & $\mathrm{X}$ & fits with 314 \\
\hline 311 & & adult & & \\
\hline 312 & & adult & & \\
\hline 313 & & adult & & \\
\hline 314 & male & adult & & fits with 309 \\
\hline 315 & & adult & & \\
\hline 316 & & adult & & \\
\hline 317 & female? & adult & $\mathrm{X}$ & fits with 307 and 1913 \\
\hline 318 & male? & adult & $\mathrm{X}$ & \\
\hline 342 & & adult & $\mathrm{X}$ & \\
\hline 343 & & adult & & \\
\hline 351 & & adult & & \\
\hline 352 & & adult & & \\
\hline 363 & female & adult & $\mathrm{X}$ & fits with 295 \\
\hline 364 (Ind 6) & & young adult & & \\
\hline 365 & & adult & & \\
\hline 366 & & adult & & \\
\hline 1913 & female? & adult & & fits with 307 and 317 \\
\hline 3200 & & adult & & \\
\hline 4352 & & young adult & & \\
\hline
\end{tabular}

A majority $(n=9)$ of the injuries were located near the top of the head, above the so-called 'hat brim line' (Kremer \& Sauvageau 2009). Two of the affected individuals were female, and four were male. Both females exhibited evidence of multiple instances of trauma to the back of the head (one of them also displayed a healed fracture on the right temporal bone), whereas the males exhibited a single traumatic event to the top of the head or to the face (Figure 5). The single mandible shows a healed injury 

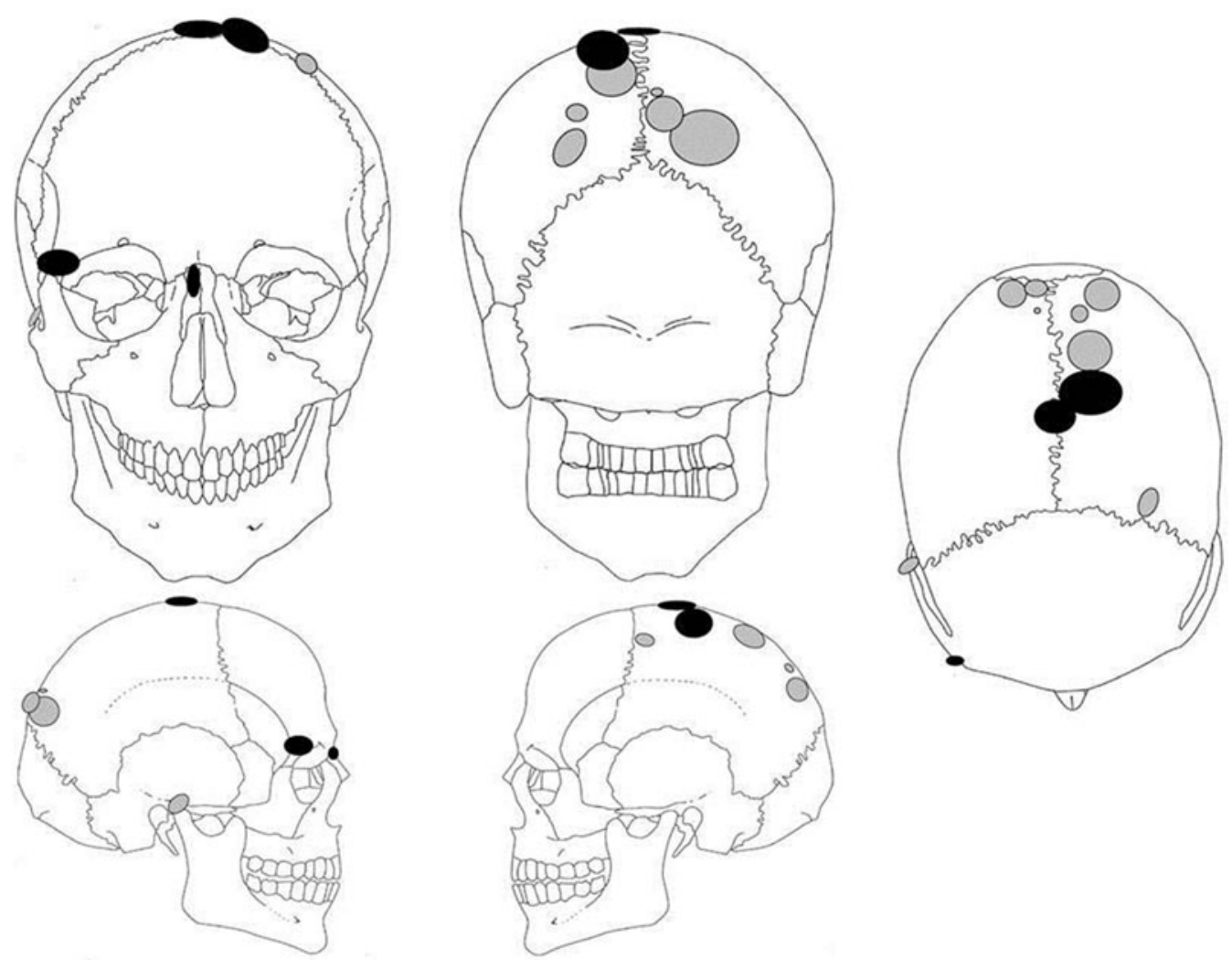

Figure 5. Location of blunt force trauma on female (grey markings) and male (black markings) crania, respectively.

to the left mandibular head. The injury may be related to trauma and dislocation of the joint.

Three of the male crania exhibited possible perimortem sharp force trauma (see S4). One incised wound was located on the right parietal bone parallel to the sagittal suture. The second injury comprised several shallow, linear incisions on a left temporal bone. The third potential sharp force wound was a horizontal fracture that radiated in an anterior-posterior direction on the left parietal bone. The wound was altered by postmortem damage, which partly destroyed the fracture margin. All incisions were shallow and only cut through the outer table of the bones. Postcranially, one right femur exhibited three shallow, parallel linear incisions near the popliteal surface.

The preservation of organic matter (e.g. collagen) affects the plastic response of bone to mechanical forces. Smooth perimortem fractures in fresh bone present obtuse or acute angles, while such trauma in dry bones produces transverse fractures with ragged and flaked margins (Ubelaker 2015). Hence, the deposition of the bones in a wet environment complicates interpretations, as postmortem trauma may show similarities to perimortem trauma (Kjellström \& Hamilton 2014). This affects the analysis of the perimortem sharp force trauma in the sample, as it does not allow for interpretations of the timing of the trauma. The cranium in which the left temporal bone exhibited sharp force incisions was, (C) Antiquity Publications Ltd, 2018 


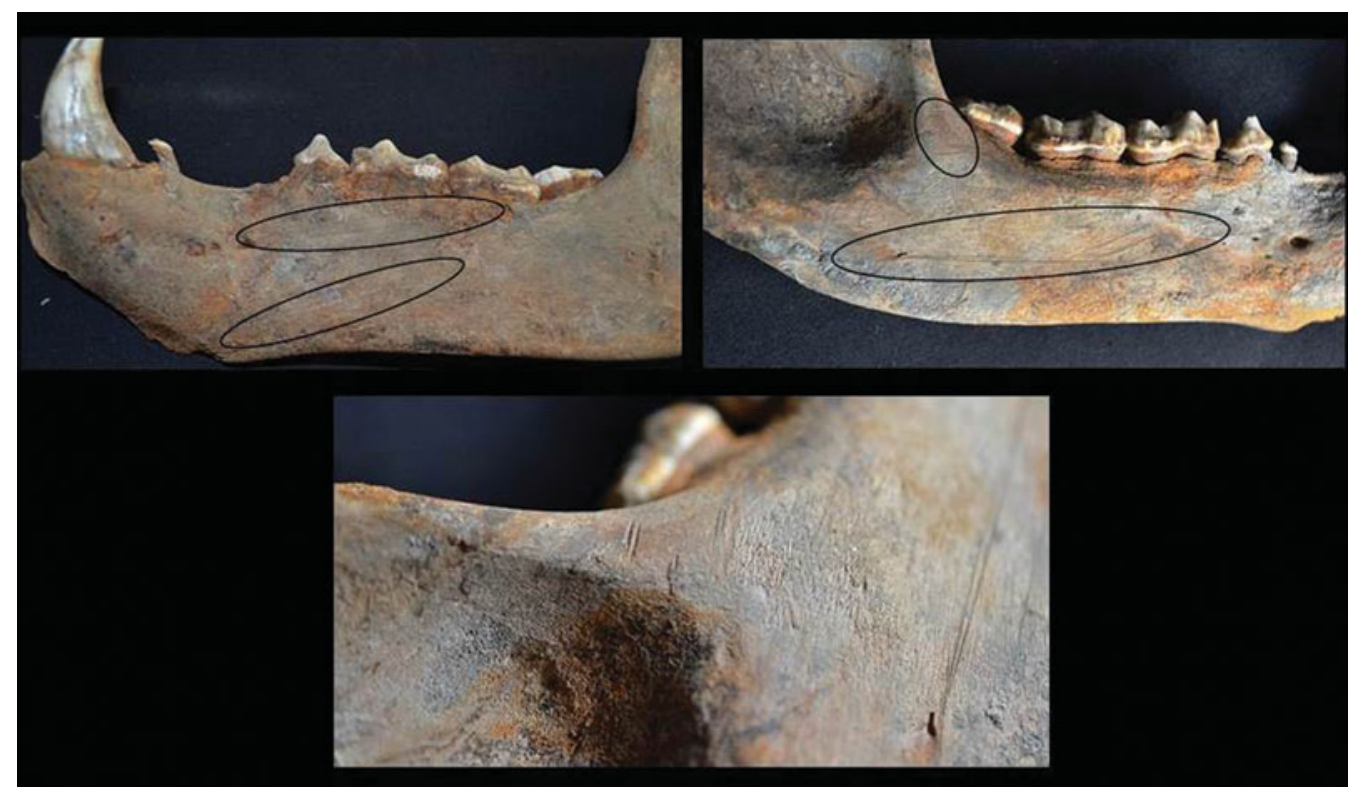

Figure 6. Cut marks on bear mandibula. Photograph: Sara Gummesson.

however, discovered with the right side facing upwards, reducing the probability of recovery damage as a causative factor for the trauma.

\section{The animal remains}

In addition to the human remains, scattered bones of at least 14 animals of 7 different species were recovered from the stone construction (see S2). Wild boar and brown bear were the most common species in the assemblage. The faunal assemblage was dominated by mandibles and post-cranial bones. Only one intact animal cranium, a badger skull with articulated mandible, was recovered. Differential element representation and observations of cut marks and fresh fractures suggest manipulation and diverse handling of the animal bodies. Perimortem sharp force trauma (butchery marks) was documented, for example, on several bear bones, indicating manipulation and disarticulation of the carcasses (Figure 6). The presence of articulated vertebrae from the lumbar region of roe deer and red deer and the cervical region of brown bear suggest varied handling of the bodies of different animals.

\section{Taphonomy, preservation and selection}

The human remains at Kanaljorden were deposited in still water. In submerged environments, bone disarticulation may result from water transportation of either complete bodies (that gradually disarticulate) or of individual elements. The skull is one of the first elements to separate from the body in water and the morphology of crania makes them vulnerable to rapid and prolonged transport. Fluvial transport often creates identifiable patterns of abrasion, particularly on the facial area, as the thin bones of the face with 


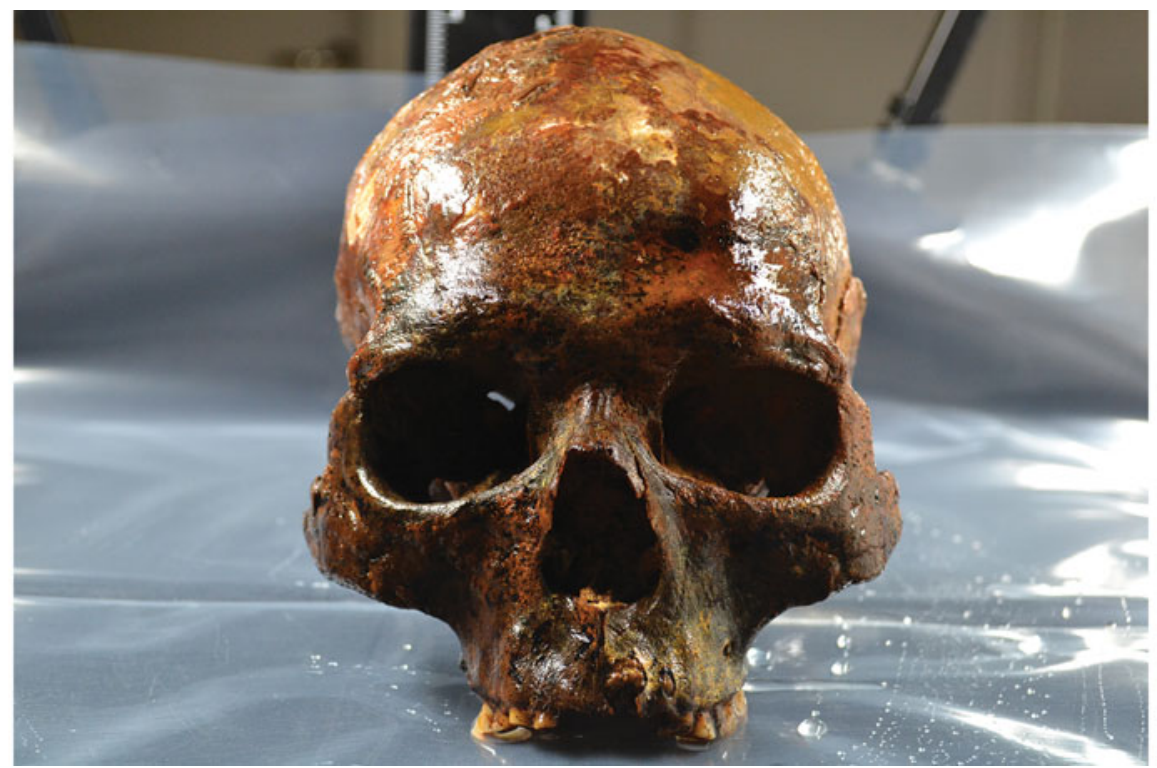

Figure 7. Anterior view of crania F296 showing well-preserved facial bones. Photograph: Sara Gummesson.

protruding processes are vulnerable to damage (Nawrocki et al. 1997). No such damage pattern or abrasion on the bones could be identified at Kanaljorden. Rather, the facial areas are fairly well preserved. The presence of small, thin bones, such as the nasal bone, on several of the crania indicated minimal water transportation (Figure 7).

The absence of mandibles (with one exception) among the human remains is notable. The articulation of the mandible is one of the first joints to disarticulate (cf. Micossi 1991: 51). Additionally, the mandible is robust, survives post-depositional processes well and is not easily moved by water (Nawrocki et al. 1997: 534; Bello \& Andrews 2006). Mandibles are common in the faunal assemblage. Thus, the absence of human mandibles is probably a consequence of intentional anthropogenic depositional practices.

The almost complete lack of sharp force trauma suggests that lower jaws were not forcibly removed, but were already disarticulated before deposition. This could have been achieved by earth-burial or exposure to the elements (although shielded from scavengers, considering the lack of gnaw marks). A possible exception is a disarticulated cranium that contained remnants of brain tissue, suggesting deposition shortly after death (cf. Doran 2002; O'Connor et al. 2011). As this skull also lacks the mandible, it was probably removed by force. For this particular find, however, the preservation of the bone was less favourable, precluding the possibility to identify cut marks. The incidence of sharp force trauma in secondary funerary practice has been proved to be generally low (Bello et al. 2016). The low incidence of identified sharp force trauma at Kanaljorden should be viewed in light of this general pattern.

Seven of the disarticulated cranial elements could be refitted, even though they were recovered more than $4 \mathrm{~m}$ apart. These finds originate from three individuals: two females (C) Antiquity Publications Ltd, 2018 
and one male. Parts of one female cranium were recovered in three areas of the stone packing, and the temporal bone was recovered inside the cranium of the other female.

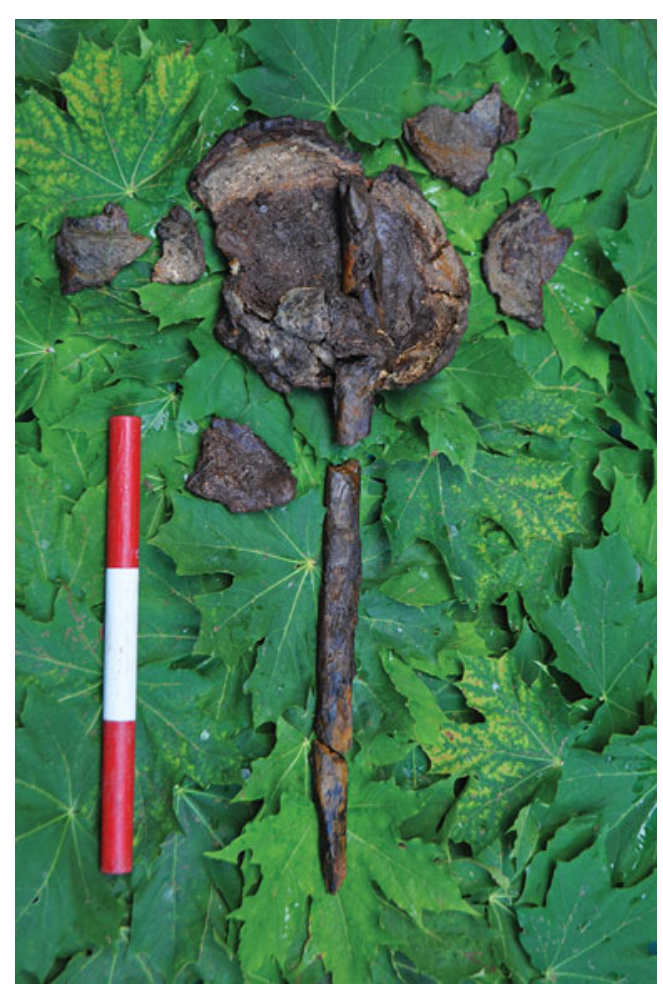

Figure 8. Cranium F318 with wooden stake. Photograph: Fredrik Hallgren.
It is possible that intact skulls may have moved in the rather calm water, as air pockets inside the skulls could have caused them to float (Boaz \& Behrensmeyer 1976). Conversely, the wooden structures might have hindered movement after deposition.

Favourable preservation conditions allowed the recovery of wooden objects. The most spectacular finds are the two wooden stakes recovered from inside two human crania. One stake was found sticking out of a cranium (Figure 8). The stake is intact, $25 \mathrm{~mm}$ wide and $0.47 \mathrm{~m}$ long, of which the last $0.2 \mathrm{~m}$ were embedded in the cranium. The opposite end of the stake is pointed. The other stake, found inside another cranium during post-excavation examination in the laboratory, was broken, with the preserved part lodged in the skull. In both cases the stakes were inserted through the foramen magnum, reaching all the way to the inner tabula. These finds show that at least two of the crania were mounted. Additionally, 400 intact and fragmentary wooden stakes were recovered, some of which may similarly have been used to mount objects (e.g. skulls, animal remains or artefacts) that have since fallen off; others are interpreted as the remains of wooden constructions, such as partitions or fences.

\section{Discussion}

The discovery of selected remains of ten Mesolithic individuals deposited on a man-made stone structure underwater is unique. The find raises questions concerning the life-history and final fate of the individuals, which may be discussed from the osteological parameters in combination with their depositional and taphonomic situation.

The incidence of trauma at Kanaljorden is high, as the majority of the crania exhibited healed blunt force trauma. The injuries affected both sexes; two females exhibited multiple traumas directed towards the back of the head and the right side. Males exhibited only a single occurrence of trauma, located on the top or the front of the skull. Healed head injuries of a similar type are known from several northern European Mesolithic populations (cf. Hutton Estabrook 2014). There are many possible explanations for the trauma patterns:

(C) Antiquity Publications Ltd, 2018 
accidents, interpersonal violence, forced abduction, spousal abuse, socially regulated nonlethal violence, or warfare (cf. Martin \& Frayer 1997; Martin et al. 2010; Hutton Estabrook \& Frayer 2013; Allen \& Jones 2014). The majority of the antemortem blunt force trauma at Kanaljorden was located above the hat brim line, suggesting violence rather than accidental injury (Kremer et al. 2008). Weapon identification is not possible and the interpretation is not clear-cut. To discriminate between falls and blows in modern settings, similar blunt force trauma needs to be combined with other criteria associated with soft tissue and the post-cranial injury patterns (Kremer \& Sauvageau 2009; Guyomarc'h et al. 2010). Although non-aggressive explanations cannot be ruled out, the number of crania with depressed fractures (some with multiple injuries) suggests some type of violence, rather than accident, as the mechanism of injury. Additionally, one of the females exhibits signs of osteoarthritis in the right temporo-mandibular joint, possibly secondary to a dislocation of the meniscus, and one of the males has a somewhat deformed nasal aperture (see S4). These skeletal changes could also tentatively be consequences of blows to the jaw and face as a result of violence.

If violence can be accepted as the causative agent, several culturally governed practices must be considered. The trauma pattern could be acknowledged as both repetitive and perhaps gender-related, as the injuries to the males are at the top of the skull, whereas those to the females are clustered at the back. In a socially stratified society, this trauma pattern could imply that the victims represented a special stigmatised group (e.g. slaves). Slavery is, however, rare among mobile hunter-gatherers (Fitzhugh 2003). It would also have been a logistical challenge for the low population density hunter-gatherers of Mesolithic central Scandinavia to keep captives for any length of time. One alternative would be to view the trauma as an outcome of inter-group violence; for example, raiding and warfare-both common occurrences among hunter-gatherers (Roscoe 2012; Allen \& Jones 2014). The gender-related trauma pattern (front/top $v$ back/side) is reminiscent of patterns observed among North American prehistoric hunter-gatherers, which have been interpreted as a result of different roles and behaviour in combat (Chatters 2014: 76). This could be associated with how individuals of different gender and age may play different roles in a combat situation (Roscoe 2009: 92).

The severity of the recorded injuries is difficult to evaluate on a personal level. The gravity of cranial trauma is most often related to endocranial damage (Wilkinson 1997: 33). Nevertheless, it is possible that the injuries had an impact on the surviving individual. Martin et al. (2010) emphasise that healed cranial depression fractures are important, as violence to the head is a most effective way of subduing an opponent or victim. Furthermore, repeated non-lethal trauma to the head will cause brain damage and neurological trauma that affects functions such as speech, memory, vision, behaviour and motor control. Such injuries could make the victim prone to more violence (i.e. injury recidivism) (Alghnam et al. 2016). The female with multiple injuries may be interpreted as having belonged to an at-risk group particularly exposed to violent acts. Marks of violence need not, however, have negative connotations, as wounds can be a source of revered status (Herdt 1987: 33, Chagnon 1992: 191-92). In traditional societies, medical disorders caused by head trauma may be interpreted as an altered state of consciousness, a gift that gives a special ability to commune with spiritual entities (Kaplan 2006). Given the lack (C) Antiquity Publications Ltd, 2018 
of complete skeletons, questions regarding post-cranial trauma patterns, child and adult health, and potential disabilities must remain unanswered. It is worth stressing that cause of death cannot be identified for any of the individuals.

Element representation at Kanaljorden raises questions of body manipulation and deposition. The intentional removal of mandibles and the separation of the skull from the body stand in contrast to reported Mesolithic burial practices in Northern Europe, where bodily integrity was often respected after interment in primary earthen burials; thus an unaltered personhood was represented (Nilsson Stutz 2003: 345-46, 350; Zagorskis 2004; Oshibkina 2008; Butrimas 2012; Nilsson Stutz et al. 2013; Liedgren 2014; Brinch Petersen 2015; Gummesson \& Molin 2016; Tõrv 2016). In Latvia, however, there are also examples where transformations of the face of the dead have been identified (Nilsson Stutz et al. 2013). In other cases, 'open' or covered burials have been reported (Brinch Petersen 2015: 93; Terberger et al. 2015). These may be seen as examples where the decomposition (and transformation) of the corpse has not been hidden. There are also examples where specific bones are missing from graves (Nilsson Stutz 2003: 310), a pattern that is often explained with reference to taphonomy or secondary disturbances. While this may be true in many instances, it could also mask a practice of manipulation, interaction and removal of buried remains (Andersson 2016). Loose human bones have been recovered from many Mesolithic sites in Northern Europe (Gray Jones 2011). These have been interpreted as remains of elaborate funerary practices where bodies were defleshed and selected bones were intentionally deposited. It has long been recognised that these may represent different aspects of the handling of the dead (Larsson et al. 1981; Lindqvist \& Possnert 1999). Similar practices have been reported from a series of Mesolithic sites in Serbia and Romania, and from Dudka in Poland (Borić 2010; Chapman et al. 2014; Bugajska 2016).

There are also several archaeological examples of skull deposits where decapitation has been documented (Frayer 1997; Bazaliiskiy \& Savelyev 2003; Orschiedt 2005; Schulting 2006). Kanaljorden differs from those sites in that there are no indications of decapitation or perimortem sharp force trauma. Ceremonial deposition of skulls is well known from the archaeological, historical and ethnographic record. There are examples of the handling and interaction of skulls of relatives in secondary burial rituals, and also examples of the display and deposition of skulls as trophies of slain enemies (Hoskins 1996; Wiessner \& Tumu 1998; Kuijt 2008; Bonogofsky 2011; Armit 2012). Sometimes trophy skulls are circulated as part of exchange systems, or are reclaimed by relatives and given a dignified burial (Hoskins 1989; Lawrence 1994: 275).

The contextual circumstances at Kanaljorden indicate that the deposits were structured and consciously arranged. The events do not appear to be random, but rather a series of conscious choices. At least two of the crania were mounted on wooden stakes. There are indications of a relatively short exposure period for at least part of the assemblage, suggested by the preserved human brain and the presence of articulated parts of animal bodies on the site. The deposition of animal remains should most probably be seen as part of the same depositional event(s), and there are indications of a strict spatial organisation. The human remains were recovered from the central part of the stone packing, whereas the majority of the faunal remains were recovered from the southern part, and with some degree of separation of different species (Figure 9). Hence, the deposition can be described as being 


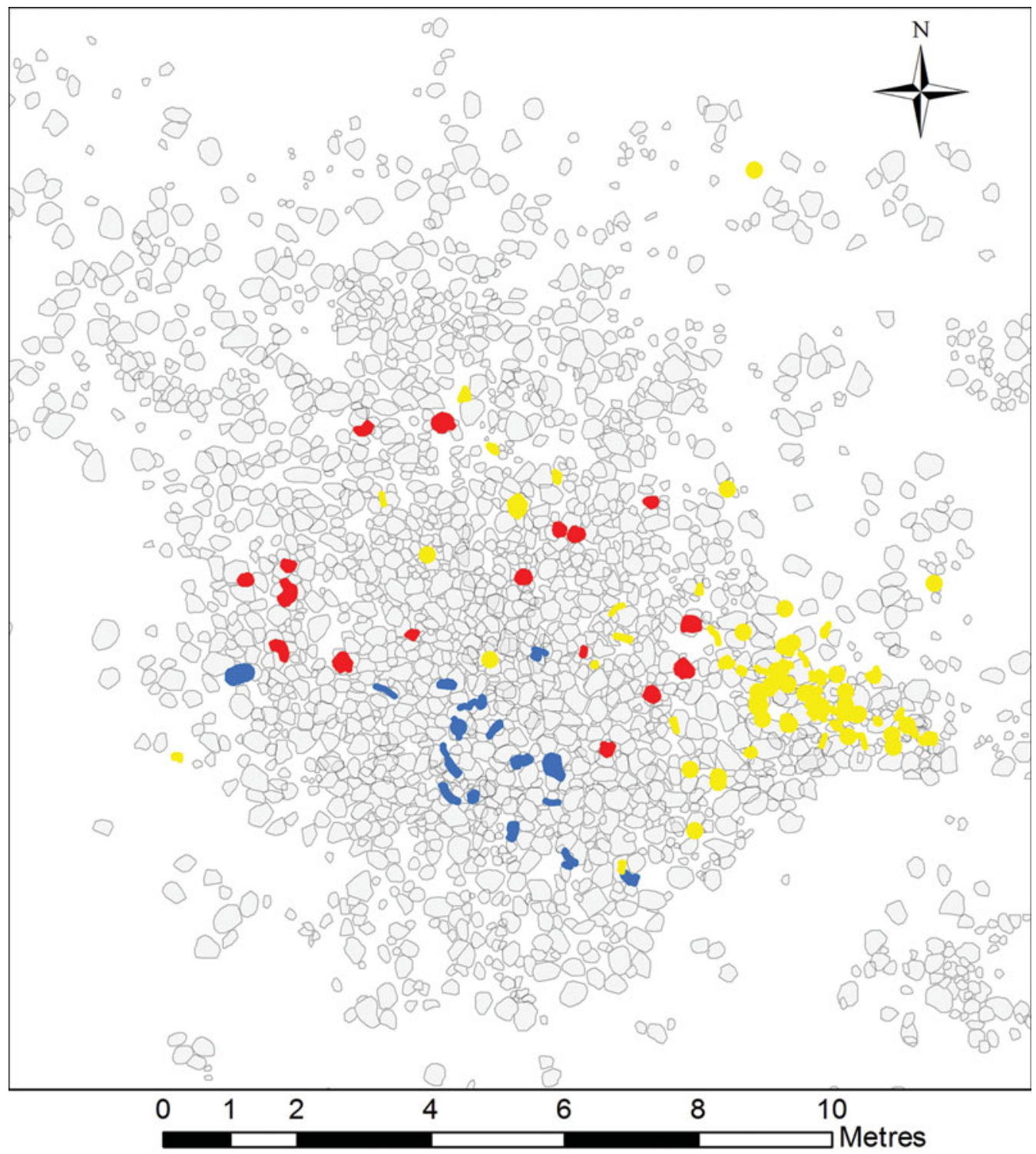

Figure 9. Spatial distribution of bones from humans (red), brown bears (blue) and wild boar (yellow) on the stone packing.

carefully planned and executed, from the construction of the underwater stone packing to the spatially separated depositions of curated human and animal remains (Hallgren et al. in press).

\section{Conclusion}

The finds of human crania and animal bones at Kanaljorden demonstrate complex depositional practices. The full evaluation of the practices is challenging, although it is (C) Antiquity Publications Ltd, 2018 
clear that human and animal bodies were manipulated prior to deposition. The osteological analysis of the human remains reveals a demographic selection favouring adult individuals, of whom several received trauma to the head before death. We have recognised a sexrelated, non-random, trauma pattern, where non-lethal forces were directed to the back of the head of women and to the top of the head of men. The fact that the majority of the individuals show healed injuries seems to be more than a coincidence and implies that they were specifically chosen for inclusion in the deposition. Soon after death, or later, their crania were brought to a small lake and deposited on a wood and stone structure in the water. The remarkable circumstances of the disarticulated bones at Kanaljorden raise the question of whether some of the loose human bones from other Mesolithic sites, or stray finds of human bones from lakes and bogs, elsewhere in Scandinavia, could be the remains of similar complex rituals.

\section{Supplementary material}

To view supplementary material for this article, please visit https://doi.org/10.15184/aqy. 2017.210

\section{References}

Alghnam, S., G.H. Tinkoff \& R. Castillo. 2016. Longitudinal assessment of injury recidivism among adults in the United States: findings from a population-based sample. Injury Epidemiology 3: 5. https://doi.org/10.1186/s40621-016-0071-x

Allen, M.W. \& T.L. Jones. 2014. Violence and warfare among hunter-gatherers. Walnut Creek (CA): Left Coast.

Andersson, H. 2016. Gotländska stenåldersstudier: människor och djur, platser och landskap. Stockholm: Stockholms universitet.

Armit, I. 2012. Headhunting and the body in Iron Age Europe. Cambridge: Cambridge University Press. https://doi.org/10.1017/CBO9781139016971

Bazaliskiy, V.I. \& N.A. Savelyev. 2003. The wolf of Baikal: the 'Lokomotiv' Early Neolithic cemetery in Siberia (Russia). Antiquity 77: 20-30. https://doi.org/10.1017/S0003598X00061317

Bello, S. \& P. Andrews. 2006. The intrinsic pattern of preservation of human skeletons and its influence on the interpretation of funerary behaviours, in R. Gowland \& C. Knüsel (ed.) Social archaeology of funerary remains: 1-13. Oxford: Oxbow.

Bello, S.M., R. Wallduck, V. Dimitrijević, I. Živaljević \& C.B. Stringer. 2016. Cannibalism versus funerary defleshing and disarticulation after a period of decay: comparisons of bone modifications from four prehistoric sites. American Journal of Physical Anthropology 161: 722-43. https://doi.org/10.1002/ajpa.23079
Boaz, N.T. \& A.K. Behrensmeyer. 1976. Hominid taphonomy: transport of human skeletal parts in an artificial fluviatile environment. Journal of Physical Anthropology 45: 53-60. https://doi.org/10.1002/ajpa.1330450107

Bonogofsky, M. 2011. The bioarchaeology of the human head: decapitation, decoration, and deformation. Gainesville: University Press of Florida. https://doi.org/10.5744/florida/ 9780813035567.001 .0001

BorIć, D. 2010. Happy forgetting? Remembering and dismembering dead bodies at Vlasac, in D. Borić. (ed.) Archaeology and memory: 48-67. Oxford: Oxbow.

Brinch Petersen, E. 2015. Diversity of Mesolithic Vedbak (Acta Archeologica 86:1). Oxford: Wiley.

- 2016. Afterlife in the Danish Mesolithic-the creation, use and discarding of 'loose human bones', in J. Grünberg, B. Gramsch, L. Larsson, J. Orschiedt \& H. Meller (ed.) Mesolithic burials — rites, symbols and social organisation of early postglacial communities: 47-62. Halle: Landesmuseums für Vorgeschichte Halle.

Bugajska, K. 2016. In the ground or in the basket? Burial wrappings from the Stone Age hunter's cemetery at Dudka, Masuria, NE-Poland. Novensia 26: 9-23.

Butrimas, A. 2012. Donkalnio ir Spigino mezolito-neolito kapinynai: Seniausieji laidojimo paminklai Lietuvoje. Vilnius: Vilnius Academy of Arts.

Chagnon, N.A. 1992. Yąnomamö. San Diego (CA): Harcourt Brace Jovanovich. 
Chapman, J., R. Wallduck \& S. Triantaphyllou. 2014. Disarticulated human bone disposal during the Mesolithic, Neolithic and Chalcolithic in the Balkans and Greece, in M. Gligor (ed.) Archaeothanatology: an interdisciplinary approach on death from prehistory to the Middle Ages. Alba Iulia: Universitatea 1 Decembrie 1918.

Chatters, J.C. 2014. Wild-type colonizers and high levels of violence among Paleoamericans, in M.W. Allen \& T.L. Jones (ed.) Violence and warfare among hunter-gatherers: 70-96. Walnut Creek (CA): Left Coast.

Doran, G.H. 2002. Windover: multidisciplinary investigations of an Early Archaic Florida cemetery. Gainesville: University Press of Florida.

Eriksson, G., K.M. Frei, R. Howcraft, S. Gummesson, F. Molin, K. Lidén, R. Frei \& F. Hallgren. 2016. Diet and mobility among Mesolithic hunter-gatherers in Motala (Sweden) - the isotope perspective. Journal of Archaeological Science: Reports. First published online 3 June 2016. https://doi.org/10.1016/j.jasrep.2016.05.052

Fitzhugh, B. 2003. The evolution of complex hunter-gatherers: archaeological evidence from the North Pacific. New York: Springer

Science+Business Media. https://doi.org/10.1007/978-1-4615-0137-4

FraYer, D.W. 1997. Ofnet: evidence for a Mesolithic massacre, in D.L. Martin \& D.W. Frayer (ed.) Violence and warfare in the past: 181-216. Amsterdam: Gordon \& Breach.

GLEncross, B.A. 2011. Skeletal injury across the life course, in S.C. Agarwal \& B.A. Glencross (ed.) Social bioarchaeology: 390-409. Chichester: Wiley-Blackwell.

Gray Jones, A. 2011. Dealing with the dead: manipulation of the body in the mortuary practices of Mesolithic north-west Europe. Manchester: University of Manchester.

GrünBERG, J. 2016. Mesolithic burials_rites, symbols and social organisation of early postglacial communities, in J. Grünberg, B. Gramsch, L. Larsson, J. Orschiedt \& H. Meller (ed.) Mesolithic burials — rites, symbols and social organisation of early postglacial communities: 13-24. Halle: Landesmuseums für Vorgeschichte Halle.

Gummesson, S. \& F. Molin. 2016. The Mesolithic cemetery at Strandvägen, Motala, in eastern central Sweden, in J. Grünberg, B. Gramsch, L. Larsson, J. Orschiedt \& H. Meller (ed.) Mesolithic burials — rites, symbols and social organisation of early postglacial communities: 145-59. Halle: Landesmuseums für Vorgeschichte Halle.
Guyomarc'h, P., M. Campagna-Vaillancourt, C. Kremer \& A. Sauvageau. 2010. Discrimination of falls and blows in blunt head trauma: a multi-criteria approach. Journal of Forensic Sciences 55: 423-27. https://doi.org/10.1111/j.15564029.2009.01310.x

Hallgren, F. \& E. Fornander. 2016. Skulls on stakes and skulls in water. Mesolithic mortuary rituals at Kanaljorden, Motala, Sweden 7000 BP, in J. Grünberg, B. Gramsch, L. Larsson, J. Orschiedt \& H. Meller (ed.) Mesolithic burials—rites, symbols and social organisation of early postglacial communities: 161-74. Halle: Landesmuseums für Vorgeschichte Halle.

Hallgren, F., S. Gummesson, K. Berggren \& J. STORÅ. In press. Human-animal symbolism within a ritual space in the Mesolithic wetland deposit at Kanaljorden, Motala, in D. Borić (ed.) Meso2015: papers presented at the $9^{\text {th }}$ International Conference on the Mesolithic in Europe, Belgrade, 2015. Oxford: Oxbow.

Herdt, G.H. 1987. The Sambia: ritual and gender in New Guinea. New York: Holt, Rinehart \& Winston.

Hoskins, J. 1989. On losing and getting a head. Warfare, exchange and alliance in a changing Sumba, 1888-1988. American Ethnologist 16: 419-40. https://doi.org/10.1525/ae.1989.16.3.02a00010

- 1996. Headhunting and the social imagination in Southeast Asia. Stanford (CA): Stanford University Press.

Hutton Estabrook, V. 2014. Violence and warfare in the European Mesolithic and Paleolithic, in M.W. Allen \& T.L. Jones (ed.) Violence and warfare among hunter-gatherers: 49-69. Walnut Creek (CA): Left Coast.

Hutton Estabrook, V. \& D.W. Frayer. 2013. Trauma in the Krapina Neandertals: violence in the Middle Palaeolithic?, in C. Knüsel \& M. Smith (ed.) The bioarchaeology of human conflict: traumatized bodies from early prehistory to the present: 67-89. London: Routledge.

Judd, M. \& R. Redfern. 2012. Trauma, in A.L. Grauer (ed.) A companion to paleopathology: 357-79. Oxford: Blackwell. https://doi.org/10.1002/9781444345940.ch20

Kaplan, R.M. 2006. The neuropsychiatry of shamanism. Before Farming 2006(4): 1-14. https://doi.org/10.3828/bfarm.2006.4.13

Kelly, R.L.1983. Hunter-gatherer mobility strategies. Journal of Anthropological Research 39: 277-306. https://doi.org/10.1086/jar.39.3.3629672 


\section{Keep your head high}

Kjellström, A. \& M. Hamilton. 2014. The taphonomy of maritime warfare: a forensic reinterpretation of sharp force trauma from the 1676 wreck of the royal Swedish warship Kronan, in D.L. Martin \& C.P. Anderson (ed.)

Bioarchaeological and forensic perspectives on violence: how violent death is interpreted from skeletal remains: 34-50. Cambridge: Cambridge University Press.

Knüsel, C. \& M. Smith (ed.). 2014. The Routledge handbook of the bioarchaeology of human conflict. London: Routledge.

Kremer, C. \& A. Sauvageau. 2009. Discrimination of falls and blows in blunt head trauma: assessment of predictability through combined criteria. Journal of Forensic Science 54: 923-26. https://doi.org/10.1111/j.15564029.2009.01072.x

Kremer, C., S. Racette, C.-A. Dionne \& A. Sauvageau. 2008. Discrimination of falls and blows in blunt head trauma: systematic study of the hat brim line rule in relation to skull fractures. Journal of Forensic Sciences 53: 716-19. https://doi.org/10.1111/j.15564029.2008.00725.x

Kuijt, I. 2008. The regeneration of life: Neolithic structures of symbolic remembering and forgetting. Current Anthropology 49: 171-97. https://doi.org/10.1086/526097

Larsson, L. 1988. The Skateholm Project I. Man and environment. Stockholm: Almqvist \& Wiksell International.

- 2000. Cemeteries and mortuary practice in the Late Mesolithic of southern Scandinavia, in V. Lang (ed.) De temporibus antiquissimis ad honorem Lembit Jaanits: 81-102. Tallinn: Ajaloo Instituudi valjaanne.

Larsson, L., C. Meiklejohn \& R.R. Newell. 1981. Human skeletal material from the Mesolithic site of Ageröd I: HC, Scania, southern Sweden. Fornvännen 76: 161-68.

Lawrence, D. 1994. Customary exchange across Torres Strait (Memoirs of the Queensland Museum 34/2). Brisbane: Queensland Museum.

Liedgren, L. 2014. Rödockragravar i Norrbotten. Arkeologi i Norr 14: 1-40.

Lindevist, C. \& G. Possnert. 1999. The first seal hunter families on Gotland: on the Mesolithic occupation in the Stora Förvar cave. Current Swedish Archaeology 7: 65-87.

Martin, D.L. \& D.W. Frayer. 1997. Troubled times: violence and warfare in the past. Amsterdam: Gordon \& Breach.
Martin, D.L., R.P. Harrod \& M. Fields. 2010. Beaten down and worked to the bone: bioarchaeological investigations of women and violence in the ancient Southwest. Landscapes of Violence 1(1): article no. 3.

Micossi, M. 1991. Postmortem change in human and animal remains. Springfield (IL): Thomas.

Molin, F., G. Gruber \& L. Hagberg. 2014. Motala-a North European focal point?, in F. Riede \& M. Tallavaara (ed.) Lateglacial and postglacial pioneers in Northern Europe (British Archaeological Reports International series 2599): 91-102. Oxford: Archaeopress.

Nawrocki, S.P., J.E. Pless, D.A. Hawley \& S.A. WAGNER. 1997. Fluvial transport of human crania, in W.D. Haglund \& M.H. Sorg (ed.) Forensic taphonomy: the postmortem fate of human remains: 529-52. Boca Raton (LA): CRC.

Nilsson Stutz, L. 2003. Embodied rituals and ritualized bodies. Tracing ritual practices in Late Mesolithic burials (Acta Archaeologica Lundensia 46). Lund: Lund University.

Nilsson Stutz, L., L. Larsson \& I. Zagorska. 2013. The persistent presence of the dead: recent excavations at the hunter-gatherer cemetery at Zvejnieki (Latvia). Antiquity 87: 1016-29. https://doi.org/10.1017/S0003598X00049838

O'Connor, S., E. Ali, S. Al-Sabah, D. Anwar, E. Bergström, K. Brown, J. Buckberry, S. Buckley, M. Collins, J. Denton, K. Dorling, A. Dowle, P. Duffey, H. Edwards, E. Correia Faria, P. Gardner, A. Gledhill, K. Heaton, C. Heron, R. Janaway, B. Keely, D. King, A. Masinton, K. Penkman, A. Petzold, M. Pickering, M. Rumsby, H. Schutkowski, K. Shackleton, J. Thomas, J. Thomas-Oates, M.-R. Usai, A. Wilson \& T. O’Connor. 2011. Exceptional preservation of a prehistoric human brain from Heslington, Yorkshire, UK. Journal of Archaeological Science 38: 2011: 1641-54. https://doi.org/10.1016/j.jas.2011.02.030

Orschiedt, J. 2005. The head burials from Ofnet Cave: an example of warlike conflict in the Mesolithic, in M. Parker Pearson \& I.J.N. Thorps (ed.) Warfare, violence and slavery in prehistory: 67-73. Oxford: Archaeopress.

Oshibkina, S.V. 2008. Mesolithic burial grounds and burial complexes in the Forest Zone of Eastern Europe. Anthropology and Archaeology of Eurasia 46(4): 46-70. https://doi.org/10.2753/AAE1061-1959460403

Roscoe, P. 2009. Social signaling and the organization of small-scale society: the case of contact-era New Guinea. Journal of Archaeological Method and Theory 16: 69-116. https://doi.org/10.1007/s10816-009-9062-3 
-2012 . Foragers and war in contact-era New Guinea, in M.W. Allen \& T.L. Jones (ed.) Violence and warfare among hunter-gatherers: 223-40. Walnut Creek (CA): Left Coast.

Schulting, R. 2006. Skeletal evidence and contexts of violence in the European Mesolithic and Neolithic, in R. Gowland \& C. Knüsel (ed.) Social archaeology of funerary remains: 224-37. Oxford: Oxbow.

Sjögren, K.-G. \& T. Аhlström. 2016. Early Mesolithic burials from Bohuslän, western Sweden, in J. Grünberg, B. Gramsch, L. Larsson, J. Orschiedt \& H. Meller (ed.) Mesolithic burials_rites, symbols and social organisation of early postglacial communities: 125-43. Halle: Landesmuseums für Vorgeschichte Halle.

Sørensen, S. 2016. Loose human bones from the Danish Mesolithic, in J. Grünberg, B. Gramsch, L. Larsson, J. Orschiedt \& H. Meller (ed.) Mesolithic burials_rites, symbols and social organisation of early postglacial communities: 63-72. Halle: Landesmuseums für Vorgeschichte Halle.

Terberger, T., A. Kotula, S. Lorenz, M. Schult, J. Burger \& B. JungkLaus. 2015. Standing upright to all eternity - the Mesolithic burial site at Groß Fredenwalde, Brandenburg (NE Germany). Quartär 62: 133-53. https://doi.org/10.7485/QU62_6
Tônv, M. 2016. Persistent practices: a multi-disciplinary study of hunter-gatherer mortuary remains from $c .6500-2600 \mathrm{cal} \mathrm{BC}$, Estonia. Unpublished $\mathrm{PhD}$ dissertation, University of Tartu.

UBELAKER, D.H. 2015. The concept of perimortem in forensic science, in K. Gerdau-Radonic \& K. McSweeney (ed.) Trends in biological anthropology, volume 1: 95-99. Oxford: Oxbow.

WALKer, P.L. 2001. A bioarchaeological perspective on the history of violence. Annual Review of Anthropology 30: 573-96. https://doi.org/10.1146/annurev.anthro.30.1.573

Wiessner, P. \& A. Tumu. 1998. Historical vines: Enga networks of exchange, ritual, and warfare in Papua New Guinea. Washington, D.C.: Smithsonian Institution.

Wilkinson, R.G. 1997. Violence against women: raiding and abduction in prehistoric Michigan, in D.L. Martin \& D.W. Frayer (ed.) Troubled times: violence and warfare in the past: 21-44. Amsterdam: Gordon \& Breach.

Zagorskis, F. 2004. Zvejnieki (northern Latvia) Stone Age cemetery. Oxford: Archaeopress.

Received: 16 December 2016; Accepted: 16 March 2017; Revised: 20 April 2017

(C) Antiquity Publications Ltd, 2018 